\title{
Gender Stereotyping of Emotions in Small Businesses and Entrepreneurial Ventures
}

\author{
Sumeet Jhamb \\ University of Alaska Anchorage \\ Teresa Ryan \\ University of Alaska Anchorage
}

This study discusses gender-emotion stereotyping and its effects on small businesses and entrepreneurial ventures and their overall strategic management. Men and women are expected to express different types of emotion in different ways according to their gender (Brescoll \& Uhlmann, 2008; Brescoll, 2016; Durik et al., 2006; Fabes \& Martin, 1991). Stereotypes are applied by individuals to others and themselves to govern and judge behavior (Plant et al., 2000). Those who act outside of societal expectations are subject to backlash by their peers, such as less respect and poor performance evaluations, with consequences on day-to-day business operations (Winkel \& Ragins, 2017). The present study examines gender-emotion stereotyping's effects on individuals and their personalities in the workplace, specifically within small businesses and entrepreneurial ventures. Through the proposed collection and analysis of secondary and primary data as well as discussion of implementing proposed solutions, this paper suggests methods and techniques to reduce gender-emotion stereotyping's adverse effects on businesses and individuals and their planned and unplanned outcomes.

Keywords: gender-emotion stereotyping, small business, entrepreneurial ventures, emotion, gender roles, stereotypes and backlash in the workplace

\section{INTRODUCTION}

Stereotypes function as a quick reaction tool, allowing individuals to rapidly form impressions of others (Heilman, 2012). However, they become problematic when too much weight is given to their accuracy and importance. Resistance against the pressure to conform to the expected stereotypes often has negative consequences. The individuals who acts outside of emotional stereotype expectations experience backlash and respond with further emotions in a downward spiral, degrading both their own emotional well-being and their status in the eyes of their peers (Winkel \& Ragins, 2017).

Of the gendered stereotypes, the most common and enduring gender-emotion stereotype experienced within workplaces is that women are overemotional in comparison to men (Brescoll, 2016; Fischback et al., 2015; Plant et al., 2000). Multiple studies have found this to be a misinterpretation of emotional expression differences between men and women (Brescoll, 2016; Fabes \& Martin, 1991; Heilman, 2012; Kelly \& Hutson-Comeaux, 1999). Rather than women experiencing more emotion at a more intense level than men, research shows that women merely tend to express certain types of emotions more often and 
more freely (Brescoll \& Uhlmann, 2008; Brescoll, 2016; Durik et al., 2006; Fabes \& Martin, 1991). The reality is that men and women are expected to display different types and levels of emotion dependent upon the context (Kelly \& Hutson-Comeaux, 1999). Certain emotions are considered masculine or feminine and the circumstances under which these emotions are to be expressed by either gender differ. Women are not expected to display all types of emotion more often than men all the time. Instead, women are expected to appropriately display emotions such as sadness, happiness, fear, jealousy, surprise, embarrassment, shame, and guilt in communal contexts (Brescoll, 2016; Durik et al, 2006; Fabes \& Martin, 1991; Fischbach et al., 2015; Zhu et al., 2020). Men are expected to display other emotions such as anger, contempt, disgust, and pride within individual context (Brescoll, 2016; Durik et al, 2006; Fabes \& Martin, 1991; Fischbach et al., 2015; Zhu et al., 2020). This gendered stereotyping of emotion is subject to confirmation bias, meaning that people tend to align with them in their own behavior, expect others to do the same, and interpret ambiguous expressions of emotion according to the stereotypes (Plant et al., 2000; Zigerell, 2017).

TABLE 1

STEREOTYPE EXPECTATIONS BY GENDER IN THE WORKPLACE

\begin{tabular}{|l|l|l|}
\hline Area by Gender & Men & Women \\
\hline Emotion & $\begin{array}{l}\text { Anger, contempt, disgust, pride, } \\
\text { aggression }\end{array}$ & $\begin{array}{l}\text { Sadness, happiness, fear, jealousy, surprise, } \\
\text { embarrassment, shame, guilt, sympathy }\end{array}$ \\
\hline Behavior & Agency, self-promotion & Communal, bargaining, advocating for others \\
\hline Business & $\begin{array}{l}\text { Management, leadership, } \\
\text { entrepreneurship }\end{array}$ & Institutional housekeeping \\
\hline
\end{tabular}

Note: Some variance by ethnicity

When individuals express emotions, or even lack of emotions, that do not align with expectations guided by stereotypes, backlash occurs (Amantuallah \& Morris, 2010; Heilman, 2012; Hess et al., 2020; Marvin et al., 2014; Ragins \& Winkel, 2011; Rudman et al., 2012). Backlash comes in many different forms in the workplace, namely less respect, lower performance evaluations, less eye contact, hostility, patronizing behavior, less attention and feedback from managers and potential employers, verbal aggression, and exclusion (Allen \& Smith, 2011; Amanatullah \& Morris, 2010; Heilman, 2012; Marvin et al., 2014). All these forms of backlash come from both male and female peers towards other men and women who act outside of stereotyped behavior (Marvin et al., 2014).

The gendering of emotions becomes problematic in business. Men who display anger and pride in the workplace are associated with higher status, while men who display sadness, guilt, and appreciation are associated with lower status (Tiedens et al., 2000). These expectations do not hold for both genders (Brescoll, 2016; Brescoll \& Uhlmann, 2008; Kelly \& Hutson-Comeaux, 1999). Many of the emotions associated with higher status in business are considered masculine and essential for managers and entrepreneurs, yet women who express masculine emotions are not seen as capable managers or leaders (Fischbach et al., 2015). Women who express anger or pride in the workplace are considered less fit for business professions and leadership positions, completely opposite the effect for men (Fischback et al., 2015). Gender-emotion stereotypes limit women in the workplace, particularly in leadership positions (Brescoll, 2016). This is not to say that men escape backlash for gendered emotions in business. Men who enter professions considered feminine are seen as weak. They are not as respected as their female counterparts or male coworkers in masculine jobs (Allen \& Smith, 2011; Heilman, 2012). Men who display feminine emotions, such as sadness, receive lower performance evaluations than men who display masculine emotions, like anger (Allen \& Smith, 2011). 
Gender-emotion stereotypes lead to underutilizing human resources, which is disadvantageous to businesses (Heilman, 2012). The following research questions in this study consider how this disadvantage can be reduced and ameliorated:

Research Question 1: Can proper awareness of gender-emotion based stereotypes reduce bias and backlash from these stereotypes to a reasonable extent?

Research Question 2: Can addressing these gender-emotion stereotypes effectively and diligently in the workplace reduce unrecognized bias and backlash from these stereotypes?

Research Question 3: Can addressing other related gender-emotion stereotypes in small businesses and entrepreneurial ventures reduce bias and backlash from these stereotypes to a reasonable extent to enhance favorable business outcomes from a strategic management perspective?

As stereotypes are often applied instinctively, it stands to reason that awareness of this tendency will allow groups and individuals to avoid the negative effects from stereotyping. The remainder of the paper seeks to understand how gender-emotion stereotypes arise, their effects on small businesses and entrepreneurial ventures, and potential approaches for reducing the negative effects from these stereotypes.

\section{LITERATURE REVIEW}

A gender-emotion stereotype is a generalization about a person's expected emotional experiences and expression based on their gender (Heilman, 2012). Gender-emotion stereotypes can be both descriptive and prescriptive, claiming what groups are like and what groups should be like respectively. Both forms of stereotypes can be harmful as both create negative responses from peers when individuals fail to fulfill the expectations (Heilman, 2012). When individuals process information, gender is processed first, then emotion (Zhu et al., 2020). Stereotypes do not influence the perception of gender, thus an individual's face is not identified as male or female based on the emotion displayed, rather the emotion displayed is interpreted based on the gender of the individual (Bijlstra et al., 2019; Zhu et al., 2020). Gender-emotion stereotyping is generally considered an automatic process, but evidence from how individuals process information suggests there is a control factor (Zhu et al., 2020). However, considering socially acceptable displays of emotion are engrained during early childhood, it is not surprising that many instinctively overapply stereotypes (Parkins, 2012). By the age of two, children refer to themselves and those around them as a boy or girl and begin associating gender with certain activities and emotions (Skočajić et al., 2020). These associations grow stronger over time as individuals age into adulthood (Skočajić et al., 2020).

Individuals are taught from an early age that women are more emotional than men. Contrary to the stereotype, research has found that men and women experience the similar types and levels of emotion, but regulate their emotional expression differently (Fabes \& Martin, 1991; Hess et al., 2010; McRae et al., 2008; Parkins, 2012; Plant et al., 2000). Participants in studies on gender-emotion stereotyping were observed to experience and express similar types and levels of emotions (Brescoll, 2016; Kelly \& HutsonComeaux, 1999; McRae et al., 2008; Plant et al., 2000). However, when asked to self-report emotions, participants confirmed gender-emotion stereotypes (Allen \& Smith, 2011; Brescoll, 2016; Heilman, 2012; Kelly \& Hutson-Comeaux, 1999; Vogel et al., 2003). Though men and women will describe their emotions in similar ways, they will report feeling types and levels of emotions in accordance with the familiar genderemotion stereotypes (Kelly \& Hutson-Comeaux, 1999). The context of the situation will also alter selfreporting. When describing public, rather than private, expression of emotion, women self-report more emotion (Kelly \& Hutson-Comeaux, 1999). This confirmation bias of stereotypes can lead to underperformance in the workplace (Roberson \& Kulik, 2007). Confirmation bias of a negative stereotype is called the stereotype threat (Roberson \& Kulik, 2007; Zigerell, 2017). For fear of a negative stereotype, individuals unwittingly act according to the stereotype. (Roberson \& Kulik, 2007). 
This same self-confirmation of the stereotypes occurs when individuals observe the behavior of others instead of just their own. In describing managers whose emotional state was not provided, respondents assumed that men made their decisions based on rationale and women made theirs for emotional reasons (Brescoll, 2016). Given that men and women do not truly experience different emotions, merely tend to express them differently according the situation and social expectations, perception becomes key to understanding gender-emotion stereotypes.

Whether or not an individual is expressing a specific emotion to the expected level, gender-emotion stereotypes are self-confirming (Plant et al., 2000). Men and women are expected to express their emotions at different levels and those expectations affect perception. Women are perceived to experience and express more love and sadness, while men are perceived to experience and express more pride and anger (Fabes \& Martin, 1991). These perceptions differ both by gender and ethnicity. European American gender stereotypes are the most gender differentiated (Durik et al., 2006). For example, European American men are perceived to express more pride and anger than European American women, but African American men and women are perceived to express similar levels of pride and anger (Durik et al., 2006; Salerno et al., 2019). In fact, African American women are generally not as strictly held to the same gender stereotypes as other ethnicities, allowing them more agency (Durik et al., 2006; Salerno, et al., 2019). Asian American women are perceived to express less emotion than European American women (Durik et al., 2006). However, Hispanic men are perceived to express more pride and aggression than European men (Durik et al., 2006).

An individual will be perceived by others according to such stereotypes and those who act outside expectations will likely experience backlash. Women are perceived to express less anger than men (Fabes \& Martin, 1991). Because women are perceived as generally less angry than men, women who express anger are seen to be expressing an emotion that is out of character and therefore perceived as more intense, that angry women are more angry than they actually are (Zhu et al., 2020). Because of the stereotype that women are more emotional than men, people are more likely to look for and judge emotional behavior or lack of emotional expression in women than men (Fabes \& Martin, 1991). Men are perceived to express less sadness and fear than women (Fabes \& Martin, 1991). Thus, men who express sadness and fear are considered weak and feminine (Allen \& Smith, 2011). In a study by Jill Allen and Jessi Smith at University of Nebraska-Lincoln and Montana State University, men who were described as displaying feminine emotions were considered less capable in their jobs (2011).

When examining the gender-stereotyped emotions, several correlated and uncorrelated themes appear. The stereotype is generally thought to apply to all emotions under all circumstances. However, studies have found the types and levels of emotional expression expected for each gender to be context specific (Kelly \& Hutson-Comeaux, 1999; Ragins \& Winkel, 2011; Vogel et al., 2003). Men are expected to display agency, while women are expected to possess communal attributes (Heilman, 2012; Vogel et al., 2003). This becomes a source for backlash particularly in business and leadership positions, where agency qualities are necessary and expected. Since the act of gaining power, via a leadership position or pay raise, are not community-centered actions, women in business experience backlash for such self-promotion (Amanatullah \& Morris, 2010). For this reason, women tend to fair worse than men in competitive negotiations, especially over salary. In a study at Columbia University of self-promoting women negotiating, they asked for nearly $\$ 8,000$ less than men or advocating women (Amanatullah \& Morris, 2010). Women are less likely to self-promote due to social expectations and pressures, and when they do, they will often experience backlash (Amanatullah \& Morris, 2010). Studies show that women are more aware of the potential for backlash and will alter or withhold their action via other behaviors including hedging and apologies to avoid backlash (Amanatullah \& Morris, 2010).

Backlash occurs in many different forms. This includes less respect, lower performance evaluations, less eye contact, hostility, patronizing behavior, less respect, less attention and feedback from managers and potential employers, verbal aggression, and exclusion (Allen \& Smith, 2011; Amanatullah \& Morris, 2010; Heilman, 2012; Marvin et al., 2014). Contrary to typical expectations, all these forms of backlash come from both male and female peers towards other men and women who act outside of stereotyped behavior (Marvin et al., 2014). While it is generally thought that backlash from acting outside stereotypes 
comes from men towards women, it is important to note that both men and women engage such behavior towards other men and women (Marvin et al., 2014). The levels of backlash rising from gender-emotion stereotyping differ for ethnicities because the levels of expected emotions differ. Hispanic American men are expected to express more emotions associated with machismo, such as aggression and dominance, than European American men, who are perceived to express the least sadness (Durik et al., 2006). In comparison to European American women, Asian American women are listed as the least likely to be promoted to leadership roles because of the tightly associated perception of them as feminine (Brescoll, 2016). African American women are perceived as far more angry than they actually are due to the 'angry Black woman' stereotype (Brescoll, 2016). On the other hand, African American women are allowed more agency than European American women (Durik et al., 2006; Salerno et al., 2019).

There are circumstances under which an individual can express emotions that are considered inappropriate for their gender and not experience backlash. Women self-promoting, expressing anger, or acting in leadership positions alone is not what incites backlash from peers, rather female agency does because it challenges gender-stereotype expectations (Rudman et al., 2012). In cases where bargaining is seen as a feminine activity, such as haggling prices at a market or thrift store or when defending a child, the backlash from negotiations does not occur (Amanatullah \& Morris, 2010). When women bargain for each other or for family, they are not expressing agency but rather communal attributes, and the potential backlash disappears (Amanatullah \& Morris, 2010). In the workplace, if an angry woman can provide an external reason for her emotion, she is not lowered in status as she would be with an internal or unnamed reason (Brescoll \& Uhlmann, 2008).

In businesses in general, women tend to feel more pressure than men to 'act right and be good' (Cochran, 2019). This tendency often manifests when women volunteer for routine institutional 'housekeeping' tasks or less frequently engage in agency and negotiate for raises or promotions (Cochran, 2019). Fear of backlash results in individuals confirming stereotypes in their own behavior (Brescoll, 2016). This leads to the underutilization of individuals in the workplace. Employees are held back by others and by themselves because of gender-emotion stereotypes. In small businesses or entrepreneurship, the expectation for women to display communal attributes in a situation where agency is required results in women suffering backlash simply because of their gender.

\section{Small Business and Entrepreneurship}

Small business and entrepreneurship are often considered male-type jobs, therefore women tend to struggle more in those professions because of their gender. Business fields in general are perceived as masculine jobs that require rationality over emotion (Rubio-Banon \& Esteban-Lloret, 2016). Because of these gender stereotypes, women are more likely to think that they lack the personality or skills required for entrepreneurship (Cochran, 2019; Gupta, Wieland, \& Turban, 2019). The number of women in entrepreneurship is significantly lower, regardless of ethnicity or geographical location (Gupta, Goktan, \& Gunay, 2014). However, a study conducted on college campuses found that while men are more likely to want to enter entrepreneurship or have a specific business idea, women are more likely to want to acquire knowledge, develop skills, and network locally (Cochran, 2019).

To avoid backlash in leadership positions, such as small business ownership, women tend to feel as though they need to alter their leadership style to approaches that are less direct and less effective (Rudman et al., 2012). For example, women negotiating for self-interest, rather than advocating for another group, are likely to set lower opening points, target points, and reserve points than men or advocating women (Amanatullah \& Morris, 2010). Women in leadership positions are less likely to engage with employees they supervise for fear of being viewed as pushy or controlling (Brescoll, 2016). On similar lines, because the ability to make rational decisions is perceived as linked to the ability to control emotional displays, women in leadership positions may act 'cold' (Brescoll, 2016). This tactic may or may not prove effective, as the lack of emotional displays by women is opposite societal expectations and tends to incur backlash.

Peers will perceive women in positions of power as overly dominant and, in turn, these women may lean into that stereotype (Brescoll, 2016). However, not all perceptions of women in leadership positions act 
against them. Women in leadership positions are evaluated better than their male counterparts, but only in the highest positions (Heilman, 2012).

Both men and women perceive women as lacking the emotional capabilities required to be effective managers (Fischback et al., 2015). Adding the label 'successful' to a female manager lessens that automatic association, but male managers to not need the label to be seen as capable (Fischback et al., 2015). In fact, successful female managers tend to demonstrate less of the emotions associate with women and more emotions associated with men (Fischback et al., 2015). The resulting predicament is women in management positions often forced to chose between appearing as a capable leader or feminine, but unable to embody both (Fischback et al., 2015). The adverse effects of gender-emotion stereotyping on businesses has initiated much research on the mental processes that encourage it and methods for preventing or reducing such bias.

\section{DISCUSSION}

\section{Research Gaps}

The research related above leave an area underdeveloped; gender-emotion stereotyping effects on minorities. While some studies have found that ethnicity influences gender-emotion stereotyping and leadership evaluations, though the main theme of overemotional women holds, researchers note much more room for exploration in this area (Durik et al., 2006; Brescoll, 2016). Gender-emotion stereotypes are strongest for European-Americans, both in regards to how much more emotional European-American women are perceived than European-American men and the number of emotions that are considered gendered (Durik et al., 2006). However, African-American women are perceived with more anger than European-American women (Durik et al., 2006). This can result in more difficulty for African-American women in leadership positions, where women expressing anger experience backlash (Brescoll, 2016; Salerno et al., 2019). Further research into the gender-emotion stereotypes of minorities may find other differences of note that will affect which methods for reducing bias and prejudice are most effective. Especially when considering that confrontations over racism are more likely to be dismissed by the confronted individual than confrontations over sexism, confronting gender-emotion stereotyping may not achieve the same level of success when the behavior is directed towards minorities (Parket et al., 2000). More research is needed to determine how much and in what other ways ethnicity affects gender-emotion stereotypes and proposed solutions to reducing bias encouraged by them.

\section{Current Research Into Gender-Emotion Stereotyping}

Studies on gender-emotion stereotyping examine the origins, mental processes, and effects. With an understanding of these, researchers can propose and analyze methods for preventing and reducing bias from these stereotypes. Many of these studies have found the basis of gender-emotion stereotypes, that women are more emotional than men, to be false (Brescoll, 2016; Fabes \& Martin, 1991; Heilman, 2012; Hess et al., 2010; Kelly \& Hutson-Comeaux, 1999; Plant et al., 2000). Primary and secondary research conducted in a study at the University of Wisconsin Madison found how men and women regulate their emotional expression differs although both groups experienced similar types and levels of emotion (Plant et al., 2000). Participants showed that individuals will interpret emotion based on gender in accordance with the genderemotion stereotypes, independent of the actual level of emotion experienced or expressed (Plant et al., 2000).

This interpretation of emotion is discussed further in an article published in the Cognition and Emotion Journal. Over the course of three studies, researchers examined emotion expression and perception in regards to gender-emotion stereotypes (Hess et al., 2010). Their findings concluded that women are expected, by each other and themselves, to express more emotions in general. Men are expected, by each other and themselves, to express less emotion in general, excluding anger (Hess et al., 2010). These expectations are engrained in children as early as three years old. Women expect of each other and themselves to react with more sadness to negative stimuli, while men expect more happiness and calmness of themselves in response to negative stimuli. However, the differences were minimal in reactions to positive stimuli (Hess et al., 2010). Other differences can be found in the information absorption process. 
A study at Bejing Normal University found that the way individuals process information impacts the level to which they apply stereotypes (Bijlstra et al., 2019; Zhu et al., 2020). Those who process top-down, abstract processing, are more likely to apply stereotypes to themselves and others, while those who process bottom-up, concrete processing, are less likely (Zhu et al., 2020).

Victoria Brescoll at Yale University of Management proffers an article that focuses specifically on how gender-emotion stereotyping influences how individuals evaluate female leaders in comparison to male leaders (2016). Her research came to a couple of conclusions. First, the fear of backlash leads women to alter their leadership styles in ways that inhibit their effectiveness as leaders (Brescoll, 2016). Female managers who fear being perceived by peers and subordinates as 'overbearing' will actively hold back, while female managers who wish to be perceived as capable will likely be seen as 'cold' for avoiding the feminine emotions expected of their gender but rejected by their role in the workplace (Brescoll, 2016). Secondly, Brescoll found that ethnicity influences gender-emotion stereotyping and leadership evaluations, though the main theme of overemotional women holds, and notes research gaps in the study of how genderemotion stereotypes affect minorities (2016).

\section{POSSIBLE THEORIES}

The studies mentioned above include a number of potential solutions for reducing or eliminating backlash from gender-emotion stereotypes. Since the stereotypes have been consistently proven selfconfirming, several of the solutions center around avoiding the stereotype as much as possible. Awareness of where pressure to conform to gender-emotion stereotypes and consequential backlash are likely to occur in the workplace allows managers to counteract and prevent negative consequences.

\section{Decreasing Backlash From Gender-Emotion Stereotyping in the Workplace}

This process of reducing negative consequences from stereotypes can begin with the hiring process. Hiring advertisements that include male or female gendered words creates an unconscious mental bias, such that potential applicants and interviewers mentally picture a male or female in the role described, as well as masculine or feminine emotional expression, and that mental image is compared to any potential candidates (Sczesny et al., 2016). Potential employers can instead use gender-neutral words to avoid limiting the diversity of their applicant pool (Sczesny et al., 2016). Increasing the diversity of the employees contributes to decreasing gender bias in the workplace (Williams \& Mihaylo, 2019). By additionally listing the specific requirements for candidates based on skills, interviewers and interviewees are directed to evaluate the position based on qualifications rather than gender biases (Williams \& Mihaylo, 2019).

On the other side of the hiring process, performance evaluations provide another avenue for gender emotion stereotyping to adversely affect employees. When evaluators do not have performance-oriented guidelines to follow, they will fall back on familiar stereotypes. To avoid performance evaluations that are overshadowed by backlash from gender-emotion stereotyping, managers can set clear objective and goals. The most effective performance evaluations focus on performance separately from potential and personality, such that biases from gender-emotion stereotypes become irrelevant (Williams \& Mihaylo, 2019). When potential and personality are considered in performance evaluations, perceptions of the individual's emotional expression comes into question and gender-emotion biases alter perception (Williams \& Dempsey, 2014). By additionally requiring evaluators to provide rationale for their decisions, they are not only held accountable but are forced to reexamine their own thought process (Williams \& Mihaylo, 2019). Transparency discourages bias (Connley, 2020; William \& Mihaylo, 2019). When bias does surface in evaluations, managers should respond appropriately, making it clear that such behavior is not appropriate or productive in the workplace (Williams \& Mihaylo, 2019).

Clarity on all company policies will reduce gender-emotion stereotypes throughout the organization (Williams \& Mihaylo, 2019). Clearly established and upheld rules for training, promoting, and salary raises will help ensure that employees are rewarded on merit rather than held back, or promoted, by biases (Williams \& Mihaylo, 2019). Managers and evaluators who focus on performance are forced to look past biases from gender-emotion stereotyping (William \& Mihaylo, 2019). When individuals are made aware 
of the potential for bias and stereotyping, they are more likely to act against the stereotype (Djikic et al., 2008).

Another approach to reducing gender-emotion stereotyping involves confrontation. A study published in the Journal of Experimental Social Psychology comparing reactions to confrontation over gender stereotyping found bias and prejudice to be reduced when the interaction was evidence-based (Parket et al., 2017). Without evidence provided during the confrontation, individuals are likely to dismiss or minimize the behavior in support of their current systems and views (Parket et al., 2017). With evidence, the confronted individual experiences guilt that guides future behavior, resulting in reduction of bias and prejudice from stereotyping (Parker et al., 2017).

In the more everyday life of a business, self-conforming gender-emotion stereotypes affect who performs which tasks. There are certain tasks in the business field that are considered feminine, a section of which can be called 'office housework' (Williams \& Mihaylo, 2019). Office housework ranges from arranging the meeting place, providing the food, and cleaning up afterwards to any other sort of task that is generally undervalued and considered administrative busywork (Williams \& Mihaylo, 2019). Women, who are more aware of the potential for backlash and the behavior they are expected to display to avoid backlash, tend to volunteer for these tasks in order to appear 'good' in the eyes of their coworkers (Amanatullah \& Morris, 2010; Brescoll, 2016; Cochran, 2019; Williams \& Mihaylo, 2019). In volunteering for these types of jobs, women confirm the stereotypes that women are best suited to 'housekeeping' rather than business (Cochran, 2019). The fear of backlash can lead women to act in ways that do not help their status in the workplace (Heilman, 2012). By assigning institutional housekeeping tasks to men and women equally, rather than asking for or accepting volunteers, women are not lead by the pressure to please by conform to gender stereotypes by volunteering for these tasks (Cochran, 2019). In the same way that rotating institutional 'housekeeping' duties reduces gender-emotion stereotypes in the workplace, rotating highstatus tasks will do the same (Williams \& Mihaylo, 2019). Managers who seek out employees beyond the 'inner circle' to handle important work or participate in important meetings are able to take advantage of the diverse workforce they hired by encouraging involvement (Williams \& Mihaylo, 2019).

When carrying out tasks that are consider more masculine, women will either act more masculine to embody the characteristics associated with the task or will actively avoid masculine behavior to avoid appearing too masculine (Williams \& Dempsey, 2014; Amanatuallah \& Morris, 2010). Aware that selfpromoting is seen as masculine, women are less likely to ask for raises and, when they do ask for raises, set lower negotiating points, acting less aggressive in negotiations than men generally do (Amanatullah \& Morris, 2010). To counter the pressure women feel to negotiated and settle for lower salaries than their male counterparts, hold these meetings in private, where women do not feel the same level of social pressure and exposure to potential backlash is minimal (Amanatuallah \& Morris, 2010). Additionally, though it might seem contradictory, encourage transparency in discussing salaries and wages among employees. Wage gaps, and other inequalities resulting from gender-emotion stereotypes, will quickly become apparent when male and female coworkers compare (Connely, 2020; Zalis, 2019). With a comparison in mind, female employees will not see their raise requests as asking for more, but rather asking for the same, which is not perceived so much as a self-promotion. On a similar note, managers can also institute 'walking meetings' where the employee and manager can converse in a less formal environment, often times moving between other meetings (Williams \& Mihaylo, 2019). Men are more comfortable approaching a manager's office and requesting a meeting time but women tend to feel as though this displays too much selfpromoting (Williams \& Mihaylo, 2019). In the context of a 'walking meeting', it will feel less like the individual is imposing on their manager's time.

\section{Decreasing Gender-Emotion Stereotyping in Small Businesses and Entrepreneurship}

Small business and entrepreneurship are associated with masculine traits such as boldness, aggression, and risk-taking (Gupta, Goktan, \& Gunay, 2014). Men and women both tend to think that women lack the skills and emotional capabilities to succeed in small business and entrepreneurship, leading to a smaller percentage of women pursuing those careers (Cochran, 2019; Gupta, Goktan, \& Gunay, 2014). However, while some personality traits are better suited to entrepreneurship and small business, entrepreneurship 
skills are for the most part learned (Cochran, 2019). A study published in the Journal of Business Venturing proposes that strengthening the association between entrepreneurship and women will increase the number of women in entrepreneurship and small businesses, diluting the stereotype that men are better at business (Gupta, Goktan, \& Gunay, 2014). A program focusing on female mentorship would encourage more women to enter entrepreneurship (Cochran, 2019). One approach to strengthening this association is to present more examples of entrepreneurs from diverse backgrounds (Cochran, 2019). Universities, where women make up over half the number of graduates but only about a third of entrepreneurship majors, can institute female mentorship programs to encourage more women to enter entrepreneurship (Cochran, 2019).

\section{RESEARCH DESIGN AND METHODS}

The solutions offered above suggest methods of reducing and perhaps preventing gender-emotion stereotyping in the workplace, where it can hinder productivity and day-to-day operations. The proposed research seeks to identify how effective these solutions may be in reality. The table below identifies business processes that are particularly susceptible to the harmful effects of gender-emotion stereotyping and proposes research methods to gain better understanding of the effectiveness of the suggested solutions. It is important to note that in all proposed areas and methods of research, researchers should be aware of the ethnic differences in gender-emotion stereotypes and how that effects the results and conclusions of the studies.

\section{TABLE 2}

\section{PROPOSED RESEARCH METHODS}

\begin{tabular}{|l|l|}
\hline Business Process & Research Method \\
\hline Hiring & $\begin{array}{l}\text { Focus group - participants read an advert for a job opening and } \\
\text { select potential interviewees based on resumes w/similar } \\
\text { qualifications, noting effects of gendered words in advert }\end{array}$ \\
\hline Performance Evaluations & $\begin{array}{l}\text { Focus group - provide different evaluation guidelines to different } \\
\text { groups, one that warns of gender-emotion stereotyping and } \\
\text { focuses on actual work performance, one that does not }\end{array}$ \\
\hline Compensation (\& Negotiations) & $\begin{array}{l}\text { Personal survey - ask participants (of both genders) which } \\
\text { scenarios they would be more comfortable negotiating for more } \\
\text { money/higher raise }\end{array}$ \\
\hline Day-to-Day & $\begin{array}{l}\text { Observational study - implement preventative measures such as } \\
\text { walking meetings to evaluate effectiveness }\end{array}$ \\
\hline
\end{tabular}

Confronting gender-emotion stereotyping will likely be met with reasonable success. When shown evidence of bias and sexism, individuals generally accepted the behavioral assessment and were less likely to perpetuate the behavior in the future (Burns \& Granz, 2020; Parker et al., 2017). Providing evidence during confrontation while maintaining a neutral attitude decreased the likelihood of dismissal by the confronted individual (Burns \& Granz, 2020; Parker et al., 2017).

Many of the suggestions for preventing or reducing gender-emotion stereotyping are intended for dayto-day operations and as such would be difficult to study in a focus group or survey. Suggestions such as walking meetings or a 'housekeeping' rotation would best be evaluated for their effectiveness in an observational study. Researchers would be able to view first-hand how such methods affect workplace interactions and gender-emotion stereotyping. 


\section{CONCLUSION}

The proposed solutions seek to prevent and reduce gender-emotion stereotyping in the workplace by increasing awareness of their occurrence, eliminating opportunities for stereotyping, and addressing bias when it happens. Some suggestions are designed to steer individuals, both employees and potential employees, away from stereotypes before they incur bias (Heilman, 2012). Other suggestions deal with how best to confront biased behavior after the fact to forestall recurrences (Burns \& Granz, 2020). As the most enduring gender stereotype, gender-emotion stereotyping effects the day-to-day operations of businesses, particularly small businesses and entrepreneurships, reducing the productivity and utilization of human resources (Brescoll, 2016; Fischback et al., 2015; Plant et al., 2000). Addressing the disadvantages these kinds of stereotypes present requires further research into how they occur and what methods are most effective for reducing them.

\section{REFERENCES}

Allen, J., \& Smith, J.L. (2011). The influence of sexuality stereotypes on men's experience of gender-role incongruence. Psychology of Men \& Masculinity, 12(1), 77-96. doiorg.proxy.consortiumlibrary.org/10.1037/a0019678

Amanatullah, E.T., \& Morris, M.W. (2010). Negotiating gender roles: Gender differences in assertive negotiating are mediated by women's fear of backlash and attenuated when negotiating on behalf of others. Journal of Personality and Social Psychology, 98(2), 256-267. https://doiorg.proxy.consortiumlibrary.org/10.1037/a0017094

Bijlstra, G., Holland, R.W., Dotsch, R., \& Wigboldus, D.J. (2019). Stereotypes and prejudice affect the recognition of emotional body postures. American Psychology Association, 19(2), 189-199. Retrieved from http://web.a.ebscohost.com.proxy.consortiumlibrary.org/ehost/detail/ detail?vid=0\&sid=4ea41938-0c4d-407a-bc62-e1 a502093c00\%40sessionmgr4008 \&bdata=JnNpdGU9ZWhvc3QtbG12ZQ\%3d\%3d\#AN=2018-12211-001\&db=pdh

Brescoll, V.L. (2016). Leading with their hearts? How gender stereotypes of emotion lead to biased evaluations of female leaders. The Leadership Quarterly, 27(3), 415-428. https://doi:10.1016/j.leaqua.2016.02.005

Brescoll, V.L., \& Uhlmann, E. (2008). Can an Angry Woman Get Ahead? Status Conferral, Gender, and Expression of Emotion in the Workplace. Psychological Science, 19(3), 268-275. Retrieved from https://www.jstor.org/stable/40064922

Burns, M.D., \& Granz, E.L. (2020). Confronting Sexism: Promoting Confrontation Acceptance and Reducing Stereotyping through Stereotype Framing. Sex Roles. https://doiorg.proxy.consortiumlibrary.org/10.1007/s11199-020-01183-5

Cochran, S.L. (2019). What's Gender Got to Do with It? The Experiences of U.S. Women Entrepreneurship Students. Journal of Small Business Management, 57(1), 111-129. Wiley Online Library. https://doi-org.proxy.consortiumlibrary.org/10.1111/jsbm.12508

Connley, C. (2020). Data show pay transparency could be the No.1 solution to closing the gender pay gap. $C N B C$. Retrieved from https://www.cnbc.com/2020/02/11/data-shows-pay-transparencycould-close-the-gender-pay-gap.html

Djikic, M., Langer, E.J., \& Stapleton, S.F. (2008). Reducing Stereotyping Through Mindfulness: Effects on Automatic Stereotype-Activated Behaviors. Journal of Adult Development, 15, 106-111. https://doi-org.proxy.consortiumlibrary.org/10.1007/s10804-008-9040-0

Durik, A.M., Hyde, J.S., Marks, A.C., Roy, A.L., Anaya, D., \& Schultz, G. (2006). Ethnicity and Gender Stereotypes of Emotion. Sex Roles, 54, 429-445. Retrieved from https://link-springercom.proxy.consortiumlibrary.org/article/10.1007/s11199-006-9020-4\#citeas

Fabes, R.A., \& Martin, C.L. (1991). Gender and age stereotypes of emotionality. Personality and Social Psychology Bulletin, 17(5), 532-540. https://doi:10.1177/0146167291175008 
Fischbach, A., Lichtenthaler, P.W., \& Horstmann, N. (2015). Leadership and gender stereotyping of emotions: Think manager - think male? Journal of Personnel Psychology, 14(3), 153-162. https://doi:10.1027/1866-5888/a000136

Gupta, V.K., Goktan, A.B., \& Gunay, G. (2014). Gender differences in evaluation of new business opportunity: A stereotype threat perspective. Journal of Business Venturing, 29(2), 273-288. https://doi:10.1016/j.jbusvent.2013.02.002

Gupta, V.K., Wieland, A.M., \& Turban, D.B. (2019). Gender Characterizations in Entrepreneurship: A Multi-Level Investigation of Sex-Role Stereotypes about High-Growth Commercial, and Social Entrepreneurs. Journal of Small Business Management, 57(1), 131-153. https://doi.org/10.1111/jsbm.12495

Heilman, M.E. (2012). Gender stereotypes and workplace bias. Research in Organizational Behavior, 32, 113-135. https://doi-org.proxy.consortiumlibrary.org/10.1016/j.riob.2012.11.003

Heilman, M.E., \& Okimoto, T.G. (2007). Why are women penalized for success at male tasks?: The implied communality deficit. Journal of Applied Psychology, 92(1), 81-92. https://dx.doi.org.proxy.consortiumlibrary.org/10.1037/0021-9010.92.1.81

Hess, U., Senecal, S., Kirouac, G., Herrera, P., Philippot, P., \& Kleck, R. (2000). Emotional Expressivity in Men and Women: Stereotypes and Self-Perception. Cognition and Emotion, 14(5), 609-642. https://doi-org.proxy.consortiumlibrary.org/10.1080/02699930050117648

Kelly, J.R., \& Hutson-Comeaux, S.L. (1999). Gender-Emotion Stereotypes Are Context Specific. Sex Roles, 40, 107-120. https://doi-org.proxy.consortiumlibrary.org/10. 1023/A:1018834501996

Mavin, S., Grandy, G., \& Williams, J. (2014). Experiences of Women Elite Leaders Doing Gender: Intragender Micro-violence between Women. British Journal of Management, 25(3), 439-455. https://doi-org.proxy.consortiumlibrary.org/10.1111/1467-8551.12057

McRae, K., Ochsner, K.N., Mauss, I.B., Gabrieli, J.J.D., \& Gross, J.J. (2008). Gender Differences in Emotion Regulation: An fMRI Study of Cognitive Reappraisal. Group Processes \& Intergroup Relations, 11(2), 143-162. https://doi.org/10.1177/13684302070 88035

Parker, L.R., Monteith, M.J., Moss-Racusin, C.A., \& Van Camp, A.R. (2017). Promoting concern about gender bias with evidence-based confrontation. Journal of Experimental Social Psychology, 74, 8-23. https://doi-org.proxy.consortiumlibrary.org/10.1016/j.jesp. 2017.07.009

Parkins, R. (2012). Gender and Emotional Expressiveness: An Analysis of Prosodic Features in Emotional Expression. Griffith Working Papers in Pragmatics and Intercultural Communication, 5(1), 46-54. Retrieved from https://www.griffith.edu.au/_data/assets/pdf_file/ 0026/363680/Paper-6-Parkins-Gender-and-Emotional-Expressiveness_final.pdf

Plant, E.A., Hyde, J.S., Keltner, D., \& Devine, P.G. (2000). The gender stereotyping of emotions. Psychology of Women Quarterly, 24(1), 81-92. https://doi:10.1111/j.1471-6402.2000.tb01024.x

Ragins, B.R., \& Winkel, D.E. (2011). Gender, emotion and power in work relationships. Human Resources Management, 21(4), 377-393. https://doi-org.proxy.consortiumlibrary .org/10.1016/j.hrmr.2011.05.001

Roberson, L., \& Kulik, C. (2007). Stereotype Threat at Work. Academy of Management Perspectives, 21(2), 24-40. Retrieved from Retrieved from http://www.jstor.org/stable/27747371

Rubio-Banon, A., \& Esteban-Lloret, N. (2016). Cultural factors and gender role in female entrepreneurship. Suma de Negocios, 7(15), 9-17. Retrieved from https://www.sciencedirect.com/ science/article/pii/S2215910X15000518

Rudman, L.A., Moss-Racusin, C.A., Phelan, J.E., \& Nauts, S. (2012). Status incongruity and backlash effects: Defending the gender hierarchy motivates prejudice against female leaders. Journal of Experimental Social Psychology, 48(1), 165-179, https://doi.org/ 10.1016/j.jesp.2011.10.008

Salerno, J.M., Peter-Hagene, L.C., \& Jay, A.C.V. (2019). Women and African Americans are less influential when they express anger during group decision making. Group Processes \& Intergroup Relations, 22(1), 57-79. https://doi.org/10.1177/1368430217 702967 
Sczesny, S., Formanowicz, M., \& Moser, F. (2016). Can Gender-Fair Language Reduce Gender Stereotyping and Discrimination? Frontiers in Psychology, 7(25). https://doi.org/10. 3389\%2Ffpsyg.2016.00025

Skočajić, M.M., Radosavljević, J.G., Okičić, M.G., Jankovic, I.O., \& Zezelj, I.L. (2020). Boys Just Don't! Gender Stereotyping and Sanctioning of Counter-Stereotypical Behavior in Preschoolers. Sex Roles, 82, 163-172. https://doi-org.proxy.consortium library.org/10.1007/s11199-019-01051$\mathrm{x}$

Stoppard, J.M., \& Gruchy, G.C.D. (1993). Gender, Context, and Expression of Positive Emotion. Personality and Social Psychology Bulletin, 19(2), 143-150. https://doi.org/10.1177/0146167293192002

Tiedens, L.Z., Ellsworth, P.C., \& Mesquita, B. (2000). Sentimental Stereotypes: Emotional Expectations for High-and Low-Status Group Members. Personality and Social Psychology Bulletin, 26(5), 560-575. https://doi.org/10.1177/0146167200267004

Vogel, D.L., Wester, S.R., Heesacker, M., \& Madon, S. (2003). Confirming Gender Stereotypes: A Social Role Perspective. Sex Roles, 48, 519-528. https://doiorg.proxy.consortiumlibrary.org/10.1023/A:1023575212526

Williams, J.C., \& Dempsey, R. (2014). What works for women at work: Four patterns working women need to know. New York University Press. Retrieved from https://ebookcentral.proquest.com/ lib/alaskauniv-ebooks/reader.action?docID $=1572872$

Williams, J.C., \& Mihaylo, S. (2019). How the Best Bosses Interrupt Bias on Their Teams. Harvard Business Review. Retrieved from https://hbr.org/2019/11/how-the-best-bosses-interrupt-bias-ontheir-teams

Winkel, D.E., \& Ragins, B.R. (2017). Navigating the Emotional Battlefield: Gender, Power and Emotion in Entrepreneurial Relationships. Academy of Management, 2008(1). https://doi.org/10.5465/ambpp.2008.33650220

Zhu, W., Fang, P., Xing, H., Ma, Y., \& Yao, M. (2020). Not Only Top-Down: The Dual-Processing of Gender-Emotion Stereotypes. Frontiers in Psychology, 11, 1042. https://doi.org/10.3389/fpsyg.2020.01042

Zigerell, L.J. (2017). Potential Publication Bias in the Stereotype Threat Literature: Comment on Nguygen and Ryan (2008). Journal of Applied Psychology, 102(8), 1159-1168. http://dx.doi.org.proxy.consortiumlibrary.org/10.1037/ap10000188 